IJSSP

$37,7 / 8$

452

Received 12 July 2016 Accepted 12 July 2016

\section{Inheritance tax compliance - earmarking with normative value principles}

\author{
Jennifer Anna Stark and Erich Kirchler \\ Department of Applied Psychology: Work, Education, Economy, \\ Faculty of Psychology, University of Vienna, Vienna, Austria
}

\begin{abstract}
Purpose - The purpose of this paper is to investigate the relationship of inheritance tax behavior with normative value principles and factors found relevant for income tax compliance. Also, it examines the influence of affectedness and earmarking on inheritance tax compliance. Furthermore, it compares two countries similar in tax morale, tax culture as well as dominant normative value principles, Austria and Germany, of which one - Germany - levies inheritance taxes and the other - Austria - is debating its reintroduction.

Design/methodology/approach - A two (affected vs nonaffected) by two (Austria vs Germany) by two (inheritance tax vs stock profit tax) by three (no earmarking vs social justice earmarking vs equality of opportunity earmarking) experimental online questionnaire was conducted with 296 Austrians and 230 Germans. Findings - Normative value principles and other socio-psychological variables play an important role concerning inheritance tax behavior. Affectedness does not influence inheritance tax compliance. Earmarking inheritance tax to projects corresponding to these value principles increases inheritance tax compliance in the Austrian sample and could represent a measure to increase inheritance tax compliance in countries implementing inheritance tax or increasing inheritance tax.

Originality/value - This study draws a comprehensive picture of the socio-psychological variables relevant to inheritance tax behavior and tests the effect of earmarking as a policy measure to increase inheritance tax compliance.
\end{abstract}

Keywords Social justice, Equality of opportunity, Earmarking, Inheritance tax, Inheritance tax compliance, Normative value principles

Paper type Research paper

\section{Introduction}

In light of the ever increasing skewedness of the distribution of private wealth, with 1 percent of the world's population owning 48 percent of all private wealth (Hardoon, 2015), discussions about policy measures to reduce this inequality are of high sociopolitical relevance. In this discussion the taxation of intergenerational transfers of wealth represents a core topic, as inheritances play a pivotal economic and societal role in relation to the concentration of wealth within countries, accounting for 40 percent of the wealth inequality in Austria and Germany (Arbeiterkammer, 2015). To counteract this inequality, most western countries are contemplating changes in existing inheritance tax laws or the introduction (or reintroduction) of inheritance taxes where they do not currently exist. The taxation of inheritances represents a highly progressive form of redistribution, given that it only affects the wealthiest 2 percent of taxpayers (Bartels, 2005; Graetz, 2002) and most inheritance tax revenue is generated by a relatively small percentage of large

(C) Jennifer Anna Stark and Erich Kirchler. Published by Emerald Publishing Limited. This article is published under the Creative Commons Attribution (CC BY 4.0) licence. Anyone may reproduce, distribute, translate and create derivative works of this article (for both commercial \& non-commercial purposes), subject to full attribution to the original publication and authors. The full terms of this licence may be seen at http://creativecommons.org/licences/by/4.0/legalcode

An earlier version of this paper was presented at the joint IAREP/SABE/ICABEEP conference in Sibiu, Romania September 2015. The authors thank Richard Einöder and Ferdinand Halter for their collaboration in the development of material and data collection process.
International Journal of Sociology and Social Policy Vol. 37 No. $7 / 8,2$
pp. $452-467$ Emerald Publishing Limited 0144-333X DOI 10.1108/IJSSP-07-2016-0086 
inheritances (Beckert, 2008b; Bischoff and Kusa, 2015). Even so, inheritance taxes seem to be highly unpopular (Prabhakar, 2008, 2012) and controversially debated (Beckert, 2008b). Opinion polls regularly show a strong disapproval of existing inheritance taxes or opposition toward reinstating inheritance taxes (Bartels, 2005; OGM, 2012, 2013) by the general public, even though 98 percent of taxpayers would benefit from such a tax. Although the introduction of new taxes is likely to be rejected by taxpayers, as it represents a loss of freedom in disposing of one's money (Kirchler, 1997), the strong opposition to the taxation of inheritances is puzzling. While the factors guiding income tax compliance and acceptance have been comprehensively researched, little is known about inheritance tax acceptance and compliance. Prior research into this puzzling opposition toward inheritance taxes has identified citizens' concerns about being affected by such a tax, i.e., having to pay it, and resulting self-interest (Bartels, 2005; Graetz, 2002; Page et al., 2013) as a possible cause. Also, normative value principles, such as the family, social justice, equality of opportunity, and the community, which are used to legitimize or contest the taxation of inheritances and reflect conflicting views about how modern societies should regulate property rights, have been identified as causes of controversy and opposition (Beckert, $2008 \mathrm{~b}$ ), and need to be considered when changing or introducing taxation of inheritance (Beckert, 2008a). Since inheritance taxes can easily be avoided and evaded, further research into the reasons for their unpopularity and measures to raise acceptance and consequentially tax compliance is needed. Research has suggested that "earmarking," the dedication of tax revenue from one tax to a specific public service or program, could represent a measure to improve compliance as it raises acceptance of unpopular taxes (Kallbekken and Aasen, 2010; Saelen and Kallbekken, 2011) and can increase the willingness to contribute (Hundsdoerfer et al., 2011). Although earmarking of taxes has only been researched in relation to existing taxes, it could also represent a measure to increase acceptance of and compliance with new taxes. Furthermore, earmarking inheritance tax to a program or project that conforms to a dominant normative value principle could possibly enhance acceptance of and compliance with inheritance taxes.

The current study aims to investigate the relationship of inheritance tax behavior with normative value principles and factors found relevant for income tax compliance. Also, it aims to examine the effects of "affectedness" (i.e. actually having had to pay or having to pay such a tax in the future) on inheritance tax compliance. Furthermore, it aims to investigate the effects of earmarking on inheritance tax compliance by comparing Austria and Germany, two countries that are similar regarding tax morale (Halla, 2012), tax culture, dominant normative value principles (Beckert, 2008a) and the percentage of wealth inequality explained by inheritances (Arbeiterkammer, 2015). Only Germany levies inheritance taxes, but the reintroduction of inheritance taxes is intensely debated in Austria. Drawing on data gathered through an experimental questionnaire design, the paper presents comprehensive insights into the factors that guide inheritance tax behavior. The remainder of this section is organized as follows: first, inheritance tax and the situation in Austria and Germany are elaborated. Second, an overview of determinants of tax compliance is given. Third, prior research findings on inheritance taxes, in particular affectedness and normative value principles, are presented and fourth, earmarking is introduced as a policy measure.

Due to the unprecedented accumulation of private wealth in western countries since the end of Second World War, intergenerational transfers play an important role in the distribution of wealth. Estimates suggest that intergenerational transfers of private wealth will amount to 20 trillion dollars over the next 50 years (Wiktor, 2010). This amount represents a tax base that is hard to ignore. Generally speaking, inheritance tax denotes the intergenerational transfer of private wealth mortis causa (Beckert, 2008a). Inheritances can be taxed in two ways: either as inheritance tax, which is levied on the private wealth
Inheritance tax compliance 
IJSSP

$37,7 / 8$

454

inherited by the heir, or as estate tax, which is levied on the complete bequest transferred by the testator upon his or her death. While inheritance tax is common to most European countries, estate tax is particular to Anglo-Saxon countries (e.g. USA, UK; Bischoff and Kusa, 2015). The taxation of intergenerational transfers of wealth dates back to the ancient Roman Empire (Moser, 2013) and has since then been utilized by different countries and cultures as a tax-policy mechanism (Howe and Reeb, 1997; Rathbone, 1993; Scheve and Stasavage, 2011).

Two options to tax inheritances exist, namely, as a progressive tax or a flat rate tax. Both options have advantages. A progressive inheritance tax would increase the progressivity of tax systems, and thereby enhance economic efficiency and social justice (Koller, 2013). A flat rate tax would reduce administration costs and facilitate planning of bequests (Graetz, 1983, 2002). Currently, the majority of European Union member countries, among them Germany, imposes taxes on intergenerational transfers of wealth. Only nine member countries, among them Austria, do not (Merati-Kashani and Titlius, 2009). In Austria, inheritance tax was levied from 1759 to 2008 (Ministry of Finance, 2008; Slawicek, 1905). Due to a lawsuit, the Constitutional Court ruled the implemented inheritance tax as unconstitutional and as inheritance tax law was not revised, it expired. Since the 2013 national elections and the preceding electoral campaign the reintroduction of inheritance tax has been a topic of political debate. In Germany, inheritance tax has been levied since 1906. About 88 percent of German inheritances are free of tax (Statistisches Bundesamt, 2016). Of the 925.200 deaths and ensuing bequests registered in Germany in 2015, only 110.546 (12 percent) resulted in taxable inheritances (Statistisches Bundesamt, 2016, 2017). The estimated tax base for the coming decade amounts to 4.6 billion euro (Sieweck, 2011). Even though the estimated amount of intergenerational wealth transfers reaches such numbers, the tax exemptions are high and, therefore, the taxable inheritances make up a negligible percentage of all inheritances.

Implementations of inheritance taxation are unpopular and it is important to consider the controversial nature of the tax as well as the socio-psychological factors that underlie this controversy (Beckert, 2008b) if inheritance tax compliance is to be increased. While research on income tax compliance is comprehensive, little is known about inheritance tax compliance. Given the emotional (Graetz, 1983) and controversial nature of inheritance tax (Beckert, 2008a), factors influencing income tax compliance may only apply to inheritance tax compliance to a limited extent and unique determinants may be at work. Nevertheless, findings on income tax compliance are likely to be important to inheritance tax compliance and an investigation into their relation to inheritance tax compliance is essential for a more comprehensive understanding of inheritance tax acceptance and behavior.

Variables determining income tax compliance can be classified into three categories: first, economic determinants; second, socio-demographic determinants; and, third, sociopsychological determinants (Kirchler, 2007). Economic determinants include the amount of income, the tax rate, the fines for evasion, and the audit probability (Allingham and Sandmo, 1972; Srinivasan, 1973). Socio-demographic determinants include age, gender, education, and mode of employment (i.e. being employed or self-employed). Findings suggest that tax compliance is higher among older people (Andreoni et al., 1998; Hofmann et al., 2017; Kirchler and Gangl, 2013), women (Kastlunger et al., 2010; Hofmann et al., 2017; Wahl et al., 2010) and employees, since the self-employed have more possibilities to evade taxes (Hofmann et al., 2017; Kirchler, 2007; Kirchler and Gangl, 2013).

As paying taxes is a social phenomenon, economic and individual-psychological determinants do not suffice to explain tax behavior. Socio-psychological determinants are highly relevant. They include social norms and values, knowledge about taxes, a positive attitude toward taxes, and fairness as well as justice perceptions (Kirchler, 2007; Kirchler and Gangl, 2013). Taxpayers' trust in the state and in tax authorities is also positively 
associated with tax compliance (Kirchler et al., 2008; Hofmann et al., 2014) as is taxpayers' general tax morale (Feld and Frey, 2002; Torgler, 2003, 2005). Furthermore, providing taxpayers with comprehensive information about taxes increases tax compliance (Clotfelter, 1983; Kirchler et al., 2008; Park and Hyun, 2003). In addition, taxpayers' attitudes toward taxes determine their tax compliance. The more positive taxpayers' attitudes toward taxes are, the more tax compliance they show (Kirchler, 1998; Kirchler et al., 2008; Torgler and Schneider, 2005).

While inheritance tax represents a highly progressive tax policy that affects a minimal percentage of large transfers of intergenerational of wealth, its opposition by the general public is at the same time puzzling and comprehensible, due to the socio-psychological determinants that seem to underlie its acceptance. Two adverse perspectives juxtapose each other. On the one hand, preserving private wealth accumulated for future generations, on the other hand, providing distributional justice of chances and resources in society. These interests lead to different views on who has the right to benefit from the transferred private wealth and who has the right to decide about its provision (Gaisbauer et al., 2013). Hence, interest group- conflicts (Beckert, 2008b), material self-interest (Page et al., 2013), as well as affectedness (i.e. actually belonging to the two percent of citizens that inherit a taxable amount) and affectedness perceptions (i.e. believing that one will inherit a taxable amount even through one will not) (Bartels, 2005; Birney et al., 2008) have been said to be crucial.

Unlike other taxes, inheritance taxes comprise a highly emotional component, namely, the association of inheritances with loss and mourning (Graetz, 1983; Kirchler and Gangl, 2013; Levav and McGraw, 2009; Schürz, 2013; White, 2008). Not only does one grieve the loss of a beloved person, but at the same time one must pay taxes on the wealth this person accumulated during his or her lifetime (Beckert, 2008a).

Furthermore, normative value principles that are deeply rooted in views of how modern societies should function and how property and wealth should be disposed of seem to play an important role. Beckert (2008a) identifies four distinct normative value principles used to legitimize or contest the topic of inheritance taxation, namely, the family principle, the community principle, the social justice principle, and the equality of opportunity principle, as driving factors in the debate on inheritance tax. While the family principle proposes that the testator's private wealth at the same time represents the private wealth of his or her family, which survives the testator, and the theoretical shares should be distributed among family members upon death, without the state interfering by collecting taxes, the community principle stands for the responsibility of the testator to ensure that his or her private wealth is transferred to charitable institutions or foundations that promote the common good and serve the community (Beckert, 2008a). The family principle, as well as the community principle, oppose the taxation of inheritances. The principle of social justice is output-oriented and aims at correcting the unequal success of members of society by imposing the responsibility of carrying the tax burden on the most financially capable members of society, who thereby not only contribute to improving the living conditions of the less successful members of society but also to a more just distribution of private wealth within society. The equality of opportunity principle is input-oriented and aims at creating equal material starting points, chances, and resources for all members of society by redistributing private wealth through inheritance taxation (Beckert, 2008a). The dominant value principles in a country need to be considered in reforming and introducing inheritance taxes, because they serve as legitimization (Beckert, 2008b). In Austria as well as in Germany, the family principle and the social justice principle represent the dominant value principles (Beckert, 2008a).

Given the afore mentioned skewed distribution of private wealth and the potential of inheritance tax to counteract this distribution (Aaron and Munnell, 1992; Beckert, 2008a;

Inheritance tax compliance 
IJSSP

$37,7 / 8$

456

Piketty, 2014), it is imperative to investigate policy measures to induce a more positive attitude toward inheritance tax, raise its acceptance, and consequentially increase inheritance tax compliance.

Earmarking represents a policy measure that could raise the acceptance of an unpopular tax such as inheritance tax, as it has been found to change negative attitudes toward a tax and to lead to more tax compliance (Hundsdoerfer et al., 2011).

Earmarking denotes the dedication of specific tax revenues to financing specific public services or programs (Marsiliani and Renstrom, 2000), meaning that the revenues of a tax (e.g. inheritance tax) must be used to finance specific public services or projects (Michael, 2008). Earmarking can take the form of "soft" earmarking, where parts of the revenue are used to finance specific services or projects, or "hard" earmarking, where the total amount of revenue is used to finance the services or projects that they have been dedicated to. Hard earmarking implies that the revenue generated by the earmarked tax cannot be mixed with other general tax revenues. It must be used solely to finance the specific services or projects (Carling, 2007; Jackson, 2013), obliging the state to use the revenues as dedicated by law. While transparency of the use of tax revenue is thereby increased (Kallbekken et al., 2011), this practice can lead to unbalanced budgets and budget constraints due to the dependence on the amount of tax revenue generated by the earmarked tax. Nevertheless, it provides taxpayers with the possibility to demand accountability from the authorities (Dhillon and Perroni, 2001), and hence increases taxpayers' perception of control over the use of taxes.

While transparency represents an important determinant of tax compliance (Alm et al., 2010; Kirchler et al.,2008), the relevance of the correspondence of the earmarked tax with the financed public good should not be neglected (Brennan and Buchanan, 1978). Furthermore, any tax on private wealth, or in the case of inheritance tax, the intergenerational transfer of private wealth, will only be perceived as coherent and acceptable if the earmarked purpose serves society (Schürz, 2013). Thus, the dedication and design of services and projects financed by earmarked taxes, in particular such an emotionally charged tax as inheritance tax, is highly relevant. Since research has identified normative value principles as determinant in inheritance tax acceptance and legitimization (Beckert, 2008a) and earmarking has been found to increase the willingness to contribute and lessen the perceived tax burden (Hundsdoerfer et al., 2011), earmarking inheritance tax to a cause promoting social justice or equality of opportunity may increase inheritance tax acceptance and compliance. In addition, a differentiated investigation into the effects of earmarking on an existing tax and a tax in debate of being reintroduced should provide valuable insights in its effectiveness as a policy measure.

\section{Method}

\section{Participants}

The Austrian sample consisted of 296 participants (33.2 percent women) of which 138 (47 percent) described themselves as affected by an inheritance tax. Age ranged from 17 years to 90 years with a median of 35 years $(M=36.9 ; \mathrm{SD}=12.2)$. The German sample consisted of 230 participants (48.7 percent women) of which 119 (52 percent) described themselves as affected by an inheritance tax. Age ranged from 17 years to 85 years with a median of 36 years $(M=37,1 ; \mathrm{SD}=12.1)$. For a detailed description of the samples see Table I.

\section{Design and procedure}

In order to comprehensively investigate the research questions at hand, an experimental questionnaire study was applied, allowing the gathering of behavioral as well as questionnaire data and facilitating insights into cause and effect and relationships between relevant variables. A two (affected vs nonaffected) by two (Austria vs Germany) by two 


\begin{tabular}{|c|c|c|c|c|}
\hline & Austria & Germany & Total & heritance tax \\
\hline $\begin{array}{l}N \\
\text { Age }\end{array}$ & $\begin{array}{c}296 \\
36.74(12.18)\end{array}$ & $\begin{array}{c}230 \\
37.10(12.07)\end{array}$ & $\begin{array}{c}539 \\
36.86(12.20)\end{array}$ & \\
\hline $\begin{array}{l}\text { Sex } \\
\text { Men } \\
\text { Women } \\
\text { Missing data }\end{array}$ & $\begin{array}{c}66.1 \% \\
33.2 \% \\
0.7 \%\end{array}$ & $\begin{array}{c}51.3 \% \\
48.7 \% \\
0 \%\end{array}$ & $\begin{array}{c}59.7 \% \\
39.9 \% \\
0.4 \%\end{array}$ & 457 \\
\hline $\begin{array}{l}\text { Education } \\
\text { Compulsory school } \\
\text { Apprenticeship } \\
\text { Vocational school } \\
\text { Secondary school } \\
\text { College/university } \\
\text { Missing data }\end{array}$ & $\begin{array}{c}4 \% \\
11.1 \% \\
6 \% \\
35.2 \% \\
42.3 \% \\
1 \%\end{array}$ & $\begin{array}{l}1.7 \% \\
9.1 \% \\
6.5 \% \\
24.8 \% \\
57.8 \%\end{array}$ & $\begin{array}{c}3 \% \\
10 \% \\
6.5 \% \\
30.8 \% \\
49 \% \\
0.6 \%\end{array}$ & \\
\hline $\begin{array}{l}\text { Profession } \\
\text { Student } \\
\text { Blue collar worker } \\
\text { White collar worker } \\
\text { Civil servant } \\
\text { Self-employed } \\
\text { Jobless } \\
\text { Missing data }\end{array}$ & $\begin{array}{c}15.8 \% \\
5.4 \% \\
52.7 \% \\
1 \% \\
14.4 \% \\
7.8 \% \\
0.3 \%\end{array}$ & $\begin{array}{c}16.5 \% \\
3 \% \\
45.7 \% \\
7 \% \\
16.5 \% \\
7.5 \% \\
0 \%\end{array}$ & $\begin{array}{c}16 \% \\
4.3 \% \\
49.5 \% \\
3.5 \% \\
15.4 \% \\
6.7 \% \\
0.4 \%\end{array}$ & \\
\hline $\begin{array}{l}\text { Income } \\
\text { No income } \\
\text { Income (median; Euros) } \\
\text { Missing data }\end{array}$ & $\begin{array}{c}2 \% \\
<2,000 \\
0 \%\end{array}$ & $\begin{array}{c}4.3 \% \\
<2,000 \\
0 \%\end{array}$ & $\begin{array}{c}3 \% \\
<2,000 \\
0 \%\end{array}$ & $\begin{array}{r}\text { Table I. } \\
\text { Sample demographics } \\
\text { by country }\end{array}$ \\
\hline
\end{tabular}

(inheritance tax vs stock profit tax) by three (no earmarking vs social justice earmarking vs equality of opportunity earmarking) experimental online questionnaire simulating a taxpaying situation was developed and programmed with Soscisurvey. Austria and Germany were chosen as sample countries to investigate possible differences in inheritance tax behavior between countries that are similar regarding their tax morale (Halla, 2012), dominant normative value principles (Beckert, 2008a), tax culture and systems, except for inheritance tax. While Germany levies inheritance tax, Austria does not, although its reintroduction is debated. Stock profit tax was chosen as a control to investigate the effects of earmarking on inheritance tax behavior because it is comparable as a tax rate, but lacks the emotional and controversial aspects of inheritance tax. The social justice principle and the equality of opportunity principle were chosen as bases for the earmarking projects since they are redistribution oriented. Affectedness by inheritance tax served as a variable to investigate differences in inheritance tax behavior due to self-interest. It was measured by three items. If two were answered with "Yes," participants were categorized as affected. The online experimental questionnaire was run until all six conditions were filled with equal amounts of affected and nonaffected participants.

Participants were recruited via postings of the link to the experimental online questionnaire in five Austrian and German online-newspapers (e.g. faz.net, krone.at, standard. at), in ten topic-related Austrian and German websites and boards (e.g. aktien-online.at, recht. de, steuernetz.de), the six most frequently used Austrian and German online discussion websites (e.g. frauenzimmer.de, Ioff.de, seniorenforumplus50.de), social media (e.g. Facebook, LinkedIn, Xing), as well as via e-mail and through the support of the intermediation platform Competence Center Europe, the Highschool Aichach, and the EDP training institute 
IJSSP

$37,7 / 8$

458

ALGE-EDV Consulting. The newspapers, websites, boards, discussion forums, and social media used for recruitment were chosen to reach a wide array of participants with regard to age, political attitude, income, and education, and to reach balanced samples regarding affectedness by inheritance tax.

The experimental online questionnaire consisted of five sections and was accessible from 5 April 2014 to 31 May 2014 under www.soscisurvey.de/da_wirtschaft. When clicking on the link participants were introduced to the study, informed about their anonymity and the institution conducting the study, as well as randomly assigned to one of six experimental groups. First, they were asked to indicate their agreement to 12 items about normative value principles. Second, they were asked to perform a cognitive attention test, which served as a distractor. This was followed by the experimental manipulation, where participants were asked to imagine that they received $€ 200.000$, either by inheriting or on the stock market, and had to pay taxes for the received amount. The tax rate of 25 percent (€50.000) was applied in all six conditions. The tax was either earmarked or not. If it was earmarked, it was dedicated to either a project supporting social justice, or one that supports equality of opportunity. Then participants were asked to decide on the amount of taxes they were willing pay to pay by moving a slider in the range of 0 percent $(€ 0)$ to 100 percent $(€ 50.000)$. After the tax payment, participants were asked to indicate their agreement to statements on their trust in the state, their attitude toward inheritance tax, their tax morale, their attitude toward participation and earmarking of taxes. Then, participants were asked to answer socio-demographic questions and questions about their interest in/knowledge of inheritance tax, their political orientation and their affectedness by inheritance tax. Last, they were asked to answer questions about the experimental manipulation, which served as a manipulation check. The questionnaire took approximately 15 minutes to complete.

\section{Material}

The Normative Value Principles Scale served to assess participants' adherence to the normative value principles proposed by Beckert (2008a,b) and was self-developed. It consists of four subscales - the family principle scale, the community principle scale, the social justice principle, and the equality of opportunity principle scale- each comprising four items. Participants were asked to indicate their agreement with 16 statements on a six-point scale ranging from $1=\mathrm{I}$ strongly disagree to $6=\mathrm{I}$ strongly agree (e.g. family principle: "The family of the testator should have the right to decide about the asset without the interference of third parties," community principle: "In order to prevent that the family or the state receives the asset, the testator should give it to a useful purpose," social justice principle: "In my opinion, the state has the responsibility to help all those citizens in our country, who are not doing so well" and equality of opportunity principle: "The state should ensure that all citizens have equal chances in their lives").

The attitudes toward inheritance tax scale served to assess participants' evaluation of inheritance tax and was self-developed. It consists of two subscales. The first subscale comprises five statements and the second subscale comprises 12 bipolar adjective pairs. Participants were asked to indicate their agreement with the 17 items on a six-point scale ranging from $1=\mathrm{I}$ strongly disagree to $6=\mathrm{I}$ strongly agree (e.g. "In my opinion, inheritances should principally be taxed"; "In my opinion, inheritance tax is: unfair/fair; unnecessary/necessary").

Trust in the state was assessed with five items self-developed. Participants were asked to indicate their agreement with five statements on a six-point scale ranging from $1=\mathrm{I}$ strongly disagree to $6=\mathrm{I}$ strongly agree (e.g. "In my opinion, you can trust our state").

General tax morale and compliance were assessed with four items, of which one was self-developed, one was taken from Torgler (2003), and two stem from Kirchler and Wahl (2010). Participants were asked to indicate their agreement with four statements on a six-point scale 
ranging from $1=$ I strongly disagree to $6=$ I strongly agree (e.g. "If I had the possibility, I would evade taxes"; "You could intentionally declare restaurant bills for meals you had with your friends as business meals. How likely would you be to declare those restaurant bills as business meals?").

Participants' attitude toward earmarking was assessed with three self-developed items. Participants were asked to indicate their agreement with three statements on a six-point scale ranging from $1=\mathrm{I}$ strongly disagree to $6=\mathrm{I}$ strongly agree (e.g. "I think it makes sense if revenues of specific taxes, for example, a highway tax, are solely used to support specific projects like investment in transport").

The participation scale served to assess participants' attitude toward taxpayers' codetermination in the use of taxes. It was self-developed. Participants were asked to indicate their agreement with two statements on a six-point scale ranging from $1=\mathrm{I}$ strongly disagree to $6=\mathrm{I}$ strongly agree (e.g. "I would like to have a greater voice in what my tax is used for").

Participants' affectedness by inheritance tax was assessed with three self-developed items. Participants were asked to answer three questions with yes or no (e.g.; "I will inherit/ bequeath more than $200.000 € ”$ ).

All self-developed items were constructed by the authors and two master students in psychology, and were pretested. The means, standard deviations, and reliability measures of all scales can be seen in Table II.

The projects which the taxes were dedicated to in the earmarked conditions were described as follows: Helping Hands - Poverty Reduction: this project is a governmental initiative to strengthen social justice, which is fully financed by the revenue from the inheritance tax (tax on stock profits). The aim is to support people who are impoverished due to diverse circumstances. Because any person in our society should have the right to have a roof over their heads, the state provides housing opportunities for poor people thus providing them with safety and protection. Moreover, the poor are supplied with free and healthy food and beverages and their clothes are cleaned. Hygiene facilities are built and the needy get free clothes. The aim of the project is to reduce poverty in the society and to enable poor people a life worth living, to return to working life and participate in society.

Bildungsfonds (BIFO) - Education Fund: this project is a government initiative to strengthen equal opportunities, which is fully financed by the revenue from the inheritance tax/tax on stock profits. Education should be accessible to all citizens, so the project BIFO has set the goal to support the children in our country and thus ensure equal opportunities in the labor market. The amounts of financial resources made available by the revenues of the inheritance tax are used economically and educationally meaningful. Specifically, this

\begin{tabular}{|c|c|c|c|c|c|}
\hline & $N$ & $M$ & $\mathrm{SD}$ & $\alpha$ & \\
\hline Family principle & 531 & 4.31 & 1.27 & 0.82 & \\
\hline Community principle & 533 & 2.53 & 1.10 & 0.77 & \\
\hline Social justice principle & 537 & 4.25 & 1.23 & 0.87 & \\
\hline Equal opportunity principle & 532 & 4.68 & 0.99 & 0.79 & \\
\hline Attitude toward inheritance tax & 543 & 2.87 & 1.64 & 0.90 & \\
\hline Trust in the state & 535 & 2.85 & 1.11 & 0.90 & \\
\hline General tax compliance/morale & 534 & 4.43 & 1.15 & 0.76 & Table II. \\
\hline Participation & 537 & 4.56 & 1.34 & 0.73 & Means, standard \\
\hline Attitude earmarking & 536 & 4.67 & 1.20 & 0.61 & deviations, and \\
\hline Interest and knowledge & 535 & 3.28 & 1.53 & & Cronbach $\alpha$ s of \\
\hline Political orientation & 459 & 2.86 & 1.10 & & all scales \\
\hline
\end{tabular}


IJSSP

$37,7 / 8$

460

program is about promoting early childhood learning, improving language skills of the children and funding scholarships. Furthermore, parents can take part in counseling services and are supported in the financing of school supply.

\section{Results}

Regarding the relationship of inheritance tax behavior with normative value principles, attitude toward inheritance tax, trust in the state, general tax morale/compliance, participation, attitude toward earmarking, interest in and knowledge of inheritance tax, and political orientation, the results in the Austrian sample show significant negative correlations of inheritance tax behavior with the family principle $(r=-0.38, p<0.01)$ and political orientation $(r=-0.42, p<0.01)$, meaning that participants affiliating with the family principle and participants with a right-wing political orientation paid less inheritance tax. Significant positive correlations were found for the community principle $(r=0.27$, $p<0.01)$, the social justice principle $(r=0.49, p<0.01)$, the equality of opportunity principle $(r=0.38, p<0.01)$, the attitude toward inheritance tax $(r=0.60, p<0.01)$, trust in the state $(r=0.39, p<0.01)$, and general tax morale/compliance $(r=0.43, p<0.01)$. Participation $(r=-0.04, \mathrm{~ns})$, attitude toward earmarking $(r=-0.05$, ns), interest in and knowledge of inheritance tax $(r=0.03$, ns) showed no significant relationship with inheritance tax behavior. In the German sample the results show significant positive correlations of inheritance tax behavior with the social justice principle $(r=0.33, p<0.01)$, the equality of opportunity principle $(r=0.28, p<0.01)$, the attitude toward inheritance tax $(r=0.33$, $p<0.01)$, and general tax morale/compliance $(r=0.29, p<0.01)$. No significant correlations between the family principle $(r=-0.02, \mathrm{~ns})$, the community principle $(r=0.03$, ns), trust in the state $(r=0.17, \mathrm{~ns})$, participation $(r=-0.02, \mathrm{~ns})$, attitudes toward earmarking $(r=-0.03, \mathrm{~ns})$, interest in and knowledge of inheritance tax $(r=0.04$, ns), and political orientation $(r=-0.12$, ns) were found. An overview of all correlations by country can be found in Table III.

To calculate the effects of country (Austria vs Germany), tax (inheritance tax vs stock profit tax), earmarking (no earmarking vs social justice earmarking vs equality of opportunity earmarking), and affectedness (affected by inheritance tax vs non- affected by inheritance tax) on tax compliance, an ANOVA on all conditions and samples was conducted. The results show that country has a main effect on tax behavior $\left(F(1,495)=8.98, p=0.003, \eta_{p}^{2}=0.02\right)$, Germans paid more taxes than Austrians, as well as tax $(F(1,495)=6.89, p=0.009$, $\left.\eta_{p}^{2}=0.01\right)$, more taxes were paid in the stock profit conditions than in the inheritance tax conditions, and earmarking $\left(F(2,495)=4.55, p=0.01, \eta_{p}^{2}=0.02\right)$, more taxes were paid in the earmarked conditions. Affectedness did not influence tax behavior $(F(1,481)=0.02, p=0.89$, $\left.\eta_{p}^{2}=0.00\right)$.

Analyses by country revealed the main effects of tax behavior regarding tax $\left(F(1,281)=4.63, p=0.03, \eta_{p}^{2}=0.02\right)$, more taxes were paid in the stock profit tax conditions, and earmarking $\left(F(2,281)=6.10, p=0.003, \eta_{p}^{2}=0.04\right)$ more taxes were paid in the earmarked conditions, but not regarding affectedness $\left(F(1,247)=0.14, p=0.71, \eta_{p}^{2}=0.00\right)$ in the Austrian sample. In the German sample no main effects of $\operatorname{tax}(F(1,214)=2.67, p=0.10$, $\left.\eta_{p}^{2}=0.01\right)$, earmarking $\left(F(2,214)=0.05, p=0.95, \eta_{p}^{2}=0.00\right)$, or affectedness $(F(1,214)=1.91$, $\left.p=0.17, \eta_{p}^{2}=0.01\right)$ were found.

Analyses by tax showed main effects main of country $(F(1,247)=4.88, p=0.03$, $\left.\eta_{p}^{2}=0.02\right)$, Germans paid more taxes than Austrians, and earmarking $(F(2,247)=5.04$, $\left.p=0.007, \eta_{p}^{2}=0.04\right)$, Austrians paid more taxes in earmarked conditions than Germans, but not concerning affectedness $\left(F(1,248)=1.91, p=0.17, \eta_{p}^{2}=0.01\right)$ in the inheritance tax conditions. In the stock profit tax conditions, country had a main effect on tax behavior $\left(F(1,248)=4.11, p=0.04, \eta_{p}^{2}=0.02\right)$, with Germans paying more taxes than Austrians, but earmarking $\left(F(2,248)=0.42, p=0.66, \eta_{p}^{2}=0.00\right)$ and affectedness $(F(1,248)=1.91, p=0.17$, $\eta_{p}^{2}=0.01$ ) had no effect on tax behavior. 


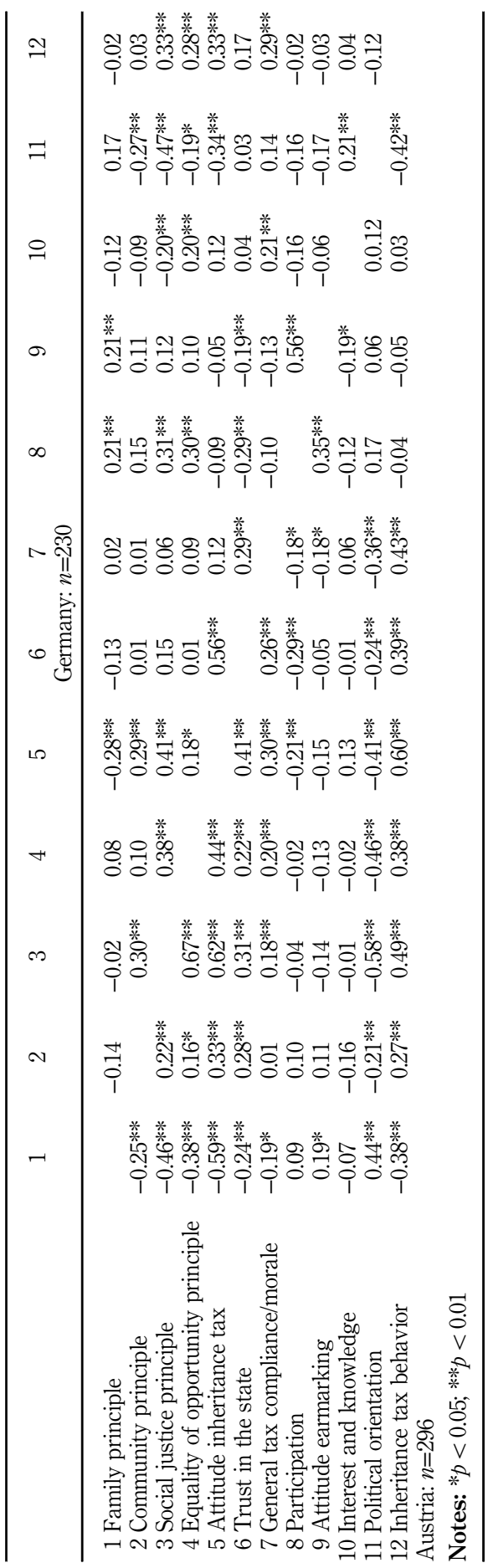

Inheritance tax compliance

Table III. Correlations of inheritance tax behavior with all scales by country 
IJSSP

$37,7 / 8$

462

In sum, Germans were more tax compliant than Austrians, regardless of the tax due. Earmarking solely affected Austrians' tax behavior in the inheritance tax conditions, and affectedness did not influence tax behavior at all. The means and standard deviations of all conditions by country can be seen in Table IV.

\section{Discussion}

This study has investigated the relationship between inheritance tax compliance and the normative value principles proposed by Beckert (2008a) and socio-psychological variables that were found relevant for tax compliance in previous tax compliance research. Furthermore, it has investigated the influence of affectedness by inheritance tax on inheritance tax compliance and earmarking, the dedication of tax revenue to a specific program, as a policy measure to increase inheritance tax compliance. It has also compared two countries (Austria and Germany) of which one (Germany) levies inheritance tax and in the other (Austria) the reintroduction of inheritance tax is debated. On the basis of a two (affected vs nonaffected) by two (Austria vs Germany) by two (inheritance tax vs stock profit tax) by three (no earmarking vs social justice earmarking vs equal opportunities earmarking) experimental online questionnaire simulating a taxpaying situation, the study has revealed key insights into the factors that drive inheritance tax behavior.

The results suggest that normative value principles play an important role in inheritance tax compliance. The direction of the relationships of inheritance tax behavior with the four value principles and attitude toward inheritance tax go in the direction proposed by Beckert (2008a) in legitimization, except for the community principle. While Beckert (2008a) suggested that people adhering to this principle oppose inheritance tax, the results show a positive relationship of the community principle with inheritance tax behavior and attitude toward inheritance tax. This result could be due to the samples investigated. Installing trusts or foundations is a practice commonly applied in Anglo- Saxon countries, in particular in the USA, but is less common in Austria and Germany. Hence, giving to the community in Austria and Germany could be associated with redistribution through taxes. In sum, these results extend Beckert's findings from discourse to a relation with actual behavior.

Attitudes toward inheritance tax play a pronounced role in inheritance tax behavior. The more positive the attitude toward this tax is, the more compliant the tax behavior is. This finding presents a possibility to increase the acceptance of inheritance tax and hence compliant tax behavior. Attitudes and normative value principles are part of peoples' social representations. While attitudes are evaluations and peripheral elements, hence can undergo change, normative value principles are deeper rooted, core elements and highly resistant to change (Stark et al., 2017). Trust in the state and general tax morale/compliance also seem to be important for inheritance tax compliance. High levels of trust and general tax morale/compliance go in hand with high levels of inheritance tax compliance. Furthermore, people adhering to the family principle trust the state less and show lower levels of general tax morale/compliance and a greater need for participation.

Table IV.

Means and standard deviations by condition and country

\begin{tabular}{lcccccr}
\hline & \multicolumn{3}{c}{ Austria } & & \multicolumn{2}{c}{ Germany } \\
Condition & $N$ & $M$ & SD & $N$ & $M$ & SD \\
\hline Inheritance tax no earmarking & \multirow{2}{*}{49} & 59.51 & 41.56 & 43 & 79.33 & 33.57 \\
Inheritance tax social justice earmarking & 44 & 77.80 & 32.64 & 39 & 83.87 & 28.04 \\
Inheritance tax equality of opportunity earmarking & 50 & 82.48 & 28.73 & 34 & 84.97 & 24.58 \\
Stock profit tax no earmarking & 54 & 77.28 & 31.90 & 39 & 88.62 & 23.59 \\
Stock profit tax social justice earmarking & 48 & 85.94 & 25.50 & 35 & 86.09 & 25.59 \\
Stock profit tax equality of opportunity earmarking & 48 & 81.77 & 28.45 & 36 & 90.36 & 20.62 \\
& & & & & &
\end{tabular}


Political orientation also plays a determining role in inheritance tax compliance. A rather right-wing orientation is associated with less inheritance tax compliance, a negative attitude toward inheritance tax, less trust in the state, and lower general tax morale. These findings correspond to findings on income tax behavior.

Comparing the Austrian and the German sample, the relationships of inheritance tax compliance and the socio-psychological variables are more pronounced in Austria. This result could stem from the fact that Austria levies no inheritance tax, but the reintroduction of this tax is hotly debated. Hence, inheritance tax represents an important and novel topic for Austrians that is present in public discourse. Individuals' social representations of the topic are still in development and consist to a great part of emotions and attitudes based on these emotions (Stark et al., 2016, 2017). Inheritance tax represents the status quo in Germany and the German sample has therefore had time to gather knowledge of and experience with the topic, and develop differentiated representations. The Austrian sample's social representation of inheritance tax, by contrast, is still in early stages of development. It consists of emotions and evaluations that are not based on knowledge or experience. It is less differentiated and hence involves higher emotional and attitudinal reactions, and also opposition as inheritance tax represents a loss in the Austrian sample (Kirchler, 1997; Stark et al., 2017).

Being affected by an inheritance tax in real life did not influence inheritance tax behavior in this study, neither in the Austrian nor the German sample. This finding contradicts the proposed importance of material self-interest of prior research on inheritance taxes (e.g. Bartels, 2005; Beckert, 2008b; Page et al., 2013) as well as other taxes (Kirchler, 1997), and gives further evidence for the unique character of inheritance taxes.

Concerning the type of tax, differences in tax compliance were only found in the Austrian sample. Austrian participants were less compliant in paying inheritance tax than paying stock profit tax, while German participants' tax compliance was not influenced by the tax they were asked to pay. These results could also be explained by a status quo perspective in the case of Germany, as both taxes are levied there. In Austria only stock profit taxes are levied, and taxes on inheritance represent the levying of new taxes, which is perceived as a loss and provokes reactance (Kirchler, 1997).

In respect to earmarking, the results show that it did not influence tax compliance in the stock profit conditions of the Austrian as well as the German sample. This result corroborates the findings of prior research that inheritance tax is emotionally charged (Graetz, 1983; Stark et al., 2016) and earmarking as a policy measure works with unpopular taxes. Regarding inheritance tax behavior, earmarking only played a role in the Austrian sample. German participants were not influenced by earmarking significantly, but the results show a trend in the proposed direction. Given the different situations regarding inheritance tax in the two sample countries, the inheritance tax levied in the study could have, as previously mentioned, represented the most extreme form of increase in taxes, namely, a new tax, and hence a loss of freedom and control for the Austrian sample, leading to opposition and tax evading behavior. In line with prior research, which indicates that earmarking increases citizens' perception of control over the use of taxes (Dhillon and Perroni, 2001), the results suggest that earmarking was able to counteract opposition and tax evading behavior by inducing a sense of control and reducing the sense of loss of freedom. For the German sample the inheritance tax levied in the study seems to have represented the status quo and subsequently tax compliant behavior occurred.

In sum, our findings show that normative value principles and other socio-psychological variables play an important role concerning inheritance tax behavior. Earmarking inheritance tax to projects corresponding to these value principles could represent a measure to increase inheritance tax compliance when introducing inheritance tax or increasing inheritance tax. Further research is needed into the effects of earmarking on inheritance tax behavior and the character of programs that would prove effective. 


\section{References}

Aaron, H.J. and Munnell, A.H. (1992), "Reassessing the role for wealth transfer taxes", National Tax Journal, Vol. 45 No. 2, pp. 119-143.

Allingham, M.G. and Sandmo, A. (1972), "Income tax evasion: a theoretical analysis", Journal of Public Economics, Vol. 1 No. 3, pp. 323-338.

Alm, J., Cherry, T., Jones, M. and McKee, M. (2010), "Taxpayer information assistance services and tax compliance behavior", Journal of Economic Psychology, Vol. 31 No. 4, pp. 577-586.

Andreoni, J., Erard, B. and Feinstein, J. (1998), "Tax compliance”, Journal of Economic Literature, Vol. 36 No. 2, pp. 818-860.

Arbeiterkammer (2015), "Reichtum wird zu großem Teil vererbt", available at: www.arbeiterkammer. at/interessenvertretung/verteilungsgerechtigkeit/Reichtum_wird_zu_grossem_Teil_vererbt. html (accessed August 27, 2017).

Bartels, L.M. (2005), "Homer gets a tax cut: inequality and public policy in the American Mind", Perspectives on Politics, Vol. 3 No. 1, pp. 15-31.

Beckert, J. (2008a), Inherited Wealth, Princeton University Press, Princeton, NJ.

Beckert, J. (2008b), "Inherited wealth. Why is the estate tax so controversial?", Society, Vol. 45 No. 6, pp. 521-528.

Birney, M., Shapiro, I. and Graetz, M.J. (2008), “ The political uses of public opinion-lessons from the estate tax repeal”, in Shapiro, I., Swenson, P.A. and Donno, D. (Eds), Divide and Deal: The Politics of Distribution in Democracies, New York University Press, New York, NY, pp. 298-29.

Bischoff, I. and Kusa, N. (2015), "Policy preferences for inheritance taxation", Working Paper No. 31, School of Business and Economics, Phillips University, Marburg, October 24.

Brennan, G. and Buchanan, J. (1978), "Tax instruments as constraints on the disposition of public revenues", Journal of Public Economics, Vol. 9 No. 3, pp. 301-318.

Carling, R. (2007), "Tax earmarking is it good practice?", Perspectives on Tax Reform, Vol. 12, CIS Policy Monograph 75, pp. vii-11.

Clotfelter, C.T. (1983), "Tax evasion and tax rates: an analysis of individual returns", The Review of Economics and Statistics, Vol. 65 No. 3, pp. 363-373.

Dhillon, A. and Perroni, C. (2001), “Tax earmarking and grass-roots accountability”, Economics Letters, Vol. 72 No. 1, pp. 99-106.

Feld, L.P. and Frey, B.S. (2002), "Trust breeds trust: how taxpayers are treated", Economics of Governance, Vol. 3 No. 2, pp. 87-99.

Gaisbauer, H.P., Neumaier, O., Schweiger, G. and Sedmak, D.C. (2013), "Erbschaftssteuer im Fokus. Zur Einleitung", in Gaisbauer, H.P., Neumaier, O., Schweiger, G. and Sedmak, C. (Eds), Erbschaftssteuer im Kontext, Springer Fachmedien, Wiesbaden, pp. 9-19.

Graetz, M.J. (1983), "To praise the estate tax, not to bury it”, The Yale Law Journal, Vol. 93, pp. 259-286.

Graetz, M.J. (2002), "100 million unnecessary returns: a fresh start for the US tax system", The Yale Law Journal, Vol. 112 No. 2, pp. 261-310.

Halla, M. (2012), "Tax morale and compliance behavior: first evidence on a causal link", The B.E. Journal of Economic Analysis \& Policy, Vol. 12 No. 1, Article 13.

Hardoon, D. (2015), "Wealth: having it all and wanting more", research report, Oxfam International, Oxford, available at: http://policy-practice.oxfam.org.uk/publications/wealth-having-it-all-andwanting-more-338125\#X8T7GQ6ShjVeZTcy.03 (accessed July 1, 2016).

Hofmann, E., Gangl, K., Kirchler, E. and Stark, J. (2014), "Enhancing tax compliance through coercive and legitimate power of tax authorities by concurrently diminishing or facilitating trust in tax authorities", Law \& Policy, Vol. 36 No. 3, pp. 290-313.

Hofmann, E., Voracek, M., Bock, Ch. and Kirchler, E. (2017), "Tax compliance across sociodemographic categories: meta-analyses of survey studies in 111 countries", Journal of Economic Psychology, Vol. 62, pp. 63-71. 
Howe, E.T. and Reeb, D.J. (1997), “The historical evolution of state and local tax systems”, Social Science Quarterly, Vol. 78 No. 1, pp. 109-121.

Hundsdoerfer, J., Sielaff, C., Blaufus, K., Kiesewetter, D. and Weimann, J. (2011), “The influence of tax labeling and tax earmarking on the willingness to contribute: a conjoint analysis", ArqusDiskussionsbeiträge zur quantitativen Steuerlehre No. 121, available at: www.econstor.eu/ dspace/bitstream/10419/49535/1/666315507.pdf (accessed August 27, 2017).

Jackson, J. (2013), “Tax earmarking, party politics and gubernatorial veto: theory and evidence from US states", Public Choice, Vol. 155 Nos 1-2, pp. 1-18.

Kallbekken, S. and Aasen, M. (2010), "The demand for earmarking: results from a focus group study", Ecological Economics, Vol. 69 No. 11, pp. 2183-2190.

Kallbekken, S., Kroll, S. and Cherry, T.L. (2011), "Do you not like Pigou, or do you not understand him? Tax aversion and revenue recycling in the lab", Journal of Environmental Economics and Management, Vol. 62 No. 1, pp. 53-64.

Kastlunger, B., Dressler, S.G., Kirchler, E., Mittone, L. and Voracek, M. (2010), "Sex differences in tax compliance: differentiating between demographic sex, gender-role orientation, and prenatal masculinization (2D:4D)", Journal of Economic Psychology, Vol. 31 No. 4, pp. 542-552.

Kirchler, E. (1997), "The burden of new taxes: acceptance of taxes as a function of affectedness and egoistic versus altruistic orientation", Journal of Socio-Economics, Vol. 26 No. 4, pp. 421-437.

Kirchler, E. (1998), "Differential representations of taxes: analysis of free associations and judgments of five employment groups", Journal of Socio-Economics, Vol. 27 No. 1, pp. 117-131.

Kirchler, E. (2007), The Economic Psychology of Tax Behaviour, Cambridge University Press, Cambrigde.

Kirchler, E. and Gangl, K. (2013), "Steuern: Widerstand und Kooperation", in Gaisbauer, H.P., Neumaier, O., Schweiger, G. and Sedmak, C. (Eds), Erbschaftssteuer im Kontext, Springer Fachmedien, Wiesbaden, pp. 229-249.

Kirchler, E. and Wahl, I. (2010), "Tax compliance inventory TAX-I: designing an inventory for surveys of tax compliance", Journal of Economic Psychology, Vol. 31 No. 3, pp. 331-346.

Kirchler, E., Hoelzl, E. and Wahl, I. (2008), "Enforced versus voluntary tax compliance: the 'slippery slope' framework”, Journal of Economic Psychology, Vol. 29 No. 2, pp. 210-225.

Koller, D.P. (2013), "Plädoyer für progressive Erbschaftssteuern", in Gaisbauer, H.P., Neumaier, O., Schweiger, G. and Sedmak, C. (Eds), Erbschaftssteuer im Kontext, Springer Fachmedien, Wiesbaden, pp. 59-79.

Levav, J. and McGraw, A.P. (2009), "Emotional accounting: how feelings about money influence consumer choice", Journal of Marketing Research, Vol. 46 No. 1, pp. 66-80.

Marsiliani, L. and Renstrom, T.I. (2000), "Time inconsistency in environmental policy: tax earmarking as a commitment solution", The Economic Journal, Vol. 110 No. 462, pp. 123-138.

Merati-Kashani, J. and Titlius, K. (2009), "Die Erbschafts- und Vermögensteuer in den EUMitgliedstaaten, Australien, Japan, Kanada und den USA", Infobrief wissenschaftlicher Dienst deutscher Bundestag, available at: http://217.79.215.140/dokumente/analysen/2009/erbschaftund_vermoegensteuer.pdf (accessed August 27, 2017).

Michael, J. (2008), "Earmarking state tax revenues", Research Department, Minnesota: House of Representatives, St Paul, available at: www.house.leg.state.mn.us/hrd/pubs/earmarking.pdf (accessed August 27, 2017).

Ministry of Finance (2008), "Information zum Auslaufen der Erbschafts- und Schenkungssteuer", available at: https://findok.bmf.gv.at/findok?execution=e1s1 (accessed August 25, 2017).

Moser, P.D. (2013), “Erben und Erbschaftssteuer in Österreich aus rechtlicher Sicht”, in Gaisbauer, H.P., Neumaier, O., Schweiger, G. and Sedmak, C. (Eds), Erbschaftssteuer im Kontext, Springer Fachmedien, Wiesbaden, pp. 99-113.

OGM (2012), “Wiedereinführung der Erbschaftssteuer?”, available at: www.ogm.at/2012/02/ wiedereinfuhrung-der-erbschaftssteuer (accessed August 27, 2017). 
IJSSP

$37,7 / 8$

OTS (2013), “Aktuelle Umfrage: Erbschaftssteuer - nein, danke”, available at: www.ots.at/ presseaussendung/OTS_20130801_OTS0016/aktuelle-umfrage-erbschaftssteuer-nein-danke (accessed August 27, 2017).

Page, B.I., Bartels, L.M. and Seawright, J. (2013), "Democracy and the policy preferences of Wealthy Americans", Perspectives on Politics, Vol. 11 No. 1, pp. 51-73.

Park, C.-G. and Hyun, J.K. (2003), "Examining the determinants of tax compliance by experimental data: a case of Korea", Journal of Policy Modeling, Vol. 25 No. 8, pp. 673-684.

Piketty, T. (2014), Capital in the Twenty-First Century, Harvard University Press, Cambridge, MA.

Prabhakar, R. (2008), "Wealth taxes: stories, metaphors and public attitudes", Political Quarterly, Vol. 79 No. 2, pp. 172-178.

Prabhakar, R. (2012), "What do public think of taxation? Evidence from a focus group study in England", Journal of European Social Policy, Vol. 22 No. 1, pp. 77-89.

Rathbone, D. (1993), "Egypt, Augustus and roman taxation", Cahiers du Centre Gustave Glotz, Vol. 4 No. 1 , pp. 81-112.

Saelen, H. and Kallbekken, S. (2011), "A choice experiment on fuel taxation and earmarking in Norway”, Ecological Economics, Vol. 70 No. 11, pp. 2181-2190.

Scheve, K. and Stasavage, D. (2011), "Democracy, war, and wealth: evidence from two centuries of estate taxation”, working paper, NYU, NYC, available at: http://government.arts.cornell.edu/ assets/psac/sp11/Stasavage_PSAC_Feb.pdf (accessed August 27, 2017).

Schürz, M. (2013), " Zu den Rechtfertigungsverhältnissen einer Erbschaftssteuer”, in Gaisbauer, H.P., Neumaier, O., Schweiger, G. and Sedmak, C. (Eds), Erbschaftssteuer im Kontext, Springer Fachmedien, Wiesbaden, pp. 207-227.

Sieweck, J. (2011), "Branchenreport Erbschaften”, BBE media.

Slawicek, R. (1905), "Zur geschichtlichen Entwicklung der österreichischen Erbsteuer”, FinanzArchiv / Public Finance Analysis, Vol. 22 No. 1, pp. 425-435.

Srinivasan, T.N. (1973), “Tax evasion: a model”, Journal of Public Economics, Vol. 2 No. 1, pp. 339-346.

Stark, J., el Sehity, T. and Kirchler, E. (2017), "Soziale Repräsentationen - soziale Vorstellungen", in Bierhoff, H.-W. and Frey, D. (Eds), Kommunikation, Interaktion und soziale Gruppenprozesse, Enzyklopädie der Psychologie, Sozialpsychologie, Hogrefe, Göttingen, pp. 63-81.

Stark, J., Kogler, Ch., Gaisbauer, H., Sedmak, C. and Kirchler, E. (2016), "Differentiating views of inheritance: the free association task as a method to assess social representations of Wealth, Inherit, and Bequeath", Review of Behavioral Economics, Vol. 3 No. 1, pp. 91-111, available at: http://dx.doi.org/10.1561/105.00000044

Statistisches Bundesamt (2016), Erbschafts- und Schenkungssteuer, Statistisches Bundesamt, Wiesbaden, available at: www.destatis.de/DE/Publikationen/Thematisch/FinanzenSteuern/ Steuern/ErbschaftSchenkungsteuer/ErbschaftSchenkungsteuer5736101157004.pdf?_blob= publicationFile (accessed August 27, 2017).

Statistisches Bundesamt (2017), Todesursachenstatistik Deutschland, Statistisches Bundesamt Deutschland, Wiesbaden, available at: www.destatis.de/DE/ZahlenFakten/GesellschaftStaat/ Gesundheit/Todesursachen/Todesursachen.html (accessed August 27, 2017).

Torgler, B. (2003), "Tax morale: theory and empirical analysis of tax compliance", $\mathrm{PhD}$ dissertation, University of Basel, Basel, available at: http://edoc.unibas.ch/56/ (accessed August 27, 2017).

Torgler, B. (2005), "Tax morale and direct democracy”, European Journal of Political Economy, Vol. 21 No. 2, pp. 525-531.

Torgler, B. and Schneider, F. (2005), "Attitudes towards paying taxes in austria: an empirical analysis", Empirica, Vol. 32 No. 2, pp. 231-250.

Wahl, I., Kastlunger, B. and Kirchler, E. (2010), "Trust in authorities and power to enforce tax compliance: an empirical analysis of the "Slippery Slope Framework", Law \& Policy, Vol. 32 No. 4, pp. 383-406, doi: 10.1111/j.1467-9930.2010.00327.x. 
White, S. (2008), "What (if anything) is wrong with inheritance tax?", The Political Quarterly, Vol. 79 Inheritance tax No. 2, pp. 162-171.

Wiktor, J. (2010), "Putting family first: intergenerational wealth transfer and investment planning", compliance Journal of Taxation of Investment, Vol. 27 No. 3, pp. 69-77.

\section{Further reading}

Beckert, J. (2005), "Political and social interests in the transfer of property", European Journal of Sociology, Vol. 46 No. 2, pp. 359-368.

Beckert, J. (2007), "The longue durée of inheritance law: discourses and institutional development in France, Germany, and the United States since 1800”, European Journal of Sociology, Vol. 48 No. 1 , pp. $79-120$.

McCleary, W. (1991), "The earmarking of government revenue: a review of some World Bank experience", The World Bank Research Observer, Vol. 6 No. 1, pp. 81-104.

Vardavas, C.I., Filippidis, F.T., Agaku, I., Mytaras, V., Bertic, M., Connolly, G.N. et al. (2012), “Tobacco taxation: the importance of earmarking the revenue to health care and tobacco control", Tobacco Induced Diseases, October 21, doi: 10.1186/1617-9625-10-21.

\section{Corresponding author}

Jennifer Anna Stark can be contacted at: jennifer.stark@univie.ac.at

For instructions on how to order reprints of this article, please visit our website: 